\title{
The theory of cross-scale interactions: an illustration from remote villages in Sikkim, India
}

\author{
Radhika Gupta $^{1}$ (D) $\cdot$ L. Jamila Haider ${ }^{1}$ (D) $\cdot$ Henrik Österblom ${ }^{1}$ (D)
}

Received: 15 March 2018 / Accepted: 12 February 2019 / Published online: 21 February 2019

(c) The Author(s) 2019

\begin{abstract}
Interdependence of social-ecological systems (SES) across the globe is rapidly increasing through increased connectivity, for example, through flow of information and trade. This case study of highly remote Himalayan villages in West Sikkim, India, explores how crossscale interactions can shape the development of a local SES. In-depth interviews across four different institutional scales-state, district, gram panchayat unit and ward, show a rapid shift from subsistence farming to commercial monocultures of large cardamom in the lowland villages of the region. This, alongside a failure to address diverse needs within the policy implementation context, has resulted in economic inequality between lowland and upland villages. The interaction between state policies for conservation, national agriculture and food subsidies, and the effects of globalization are reducing the diversity of foods for the communities, as they become dependent on external markets and government subsidies for income and food. The case study is an example of how imposing uniform institutions can threaten SES to become increasingly homogenized and vulnerable to shocks.
\end{abstract}

Keywords Cross-scale $\cdot$ Interconnected $\cdot$ Mountain systems $\cdot$ Resilience $\cdot$ Social-ecological systems $\cdot$ Sikkim

\section{Introduction}

Social-ecological systems (SES) are highly intertwined across geographical space and time (Young et al. 2006). This has become increasingly clear through the growing use of the concept of the Anthropocene, described as a new geological era, recognizing that natural processes are now human dominated (Crutzen 2006). Interdependence of SES across the globe is rapidly increasing through the flow of information, trade and other processes of connectivity associated with globalization (Liu et al. 2015a). Connected SES can behave in

Radhika Gupta

radhika.gupta@su.se

L. Jamila Haider

jamila.haider@su.se

Henrik Österblom

henrik.osterblom@su.se

1 Stockholm Resilience Centre, Stockholm University, Kräftriket 2B, 10691 Stockholm, Sweden 
nonlinear and unpredictable ways where an action in one part of the world can have a direct and immediate impact on another (Liu and Alexander 2007; Young et al. 2006).

If it is true that the entire planet is connected, then how should SES be governed for development on an interconnected Earth? Development occurs over time, at different geographical locations, in multiple institutions, and has diverse effects on actors with various incentives and priorities (Berkes 2002; Cash et al. 2006). Higher-scale institutions often assume homogeneity of contexts they seek to govern (Young 2002; Ostrom and Cox 2010) which can cause problems with institutional "fit" (Folke et al. 2007). Further, "numerous system influences and feedbacks affect management outcomes, but these feedbacks unfold under the influence of a diverse range of external influences and constraints" (Sayer et al. 2013: 8351). In order for effective cross-scale management (Berkes 2002; Ostrom and Cox 2010), there is a need to develop an understanding of linkages across social and ecological scales (Folke et al. 2010).

In this paper, we present a case study from one of the most remote regions of the world (Anonymous 2015), namely, villages in the Eastern Himalayas of India, in West Sikkim. Our aim was to understand: (1) How historical and present development of the local agriculture has been shaped by drivers of change at other geographical scales and (2) How the implications of (1) have shaped the SES capacity to cope with and adapt in the face of change (Folke et al. 2010). We addressed the question: How have local context, historical policies and interconnections across scales influenced the SES of the case study? We describe observed changes in local agricultural practices over time, through analysis of cross-scale perspectives from participants of the case study.

\section{Theoretical framework}

We construct our theoretical framework around cross-scale interactions and explain the linkages between different scales and within individual SES (Fig. 1). We use an SES lens which "emphasizes the humans-in-nature perspective" (Folke et al. 2010: 3). SES properties emerge across multiple variables of space and time due to countless interactions between social, economic, political and ecological contexts (Ludwig et al. 1993; Folke et al. 2007). The recognition of interdependent sociocultural, ecological and economic components of SES (Folke et al. 2007) allows for broader governance to fit SES attributes (Galaz et al. 2008). The opposite is defined as the problem of fit (Folke et al. 2007) and specifically as institutional misfit (Brown 2003).

Scale and cross-scale interactions are phenomena that interact either at the same scale or across scales and give rise to complex dynamics (Cash et al. 2006). Adger et al. (2006) argue that cross-scale linkages evolve and are maintained through the self-interest of organizations involved in resource management. Choosing to act on a single scale can favor or neglect certain problems (Jordan et al. 2010), thus serving the interests of powerful actors (Reid et al. 2006). Therefore, cross-scale interactions can either increase or decrease the resilience of any system with or without deliberation. Resilience is defined as "the ability of a system to absorb disturbance and still retain its basic function and structure" (Walker and Salt 2006: 1).

From a conceptual and theoretical perspective, maintaining the diversity of local SES creates heterogeneity of components, which provide options in the time of shocks and uncertainty (Kotschy et al. 2015) and increases social-ecological resilience. Conversely, homogenization of SES leaves fewer options (for example, the case of the Norway spruce 


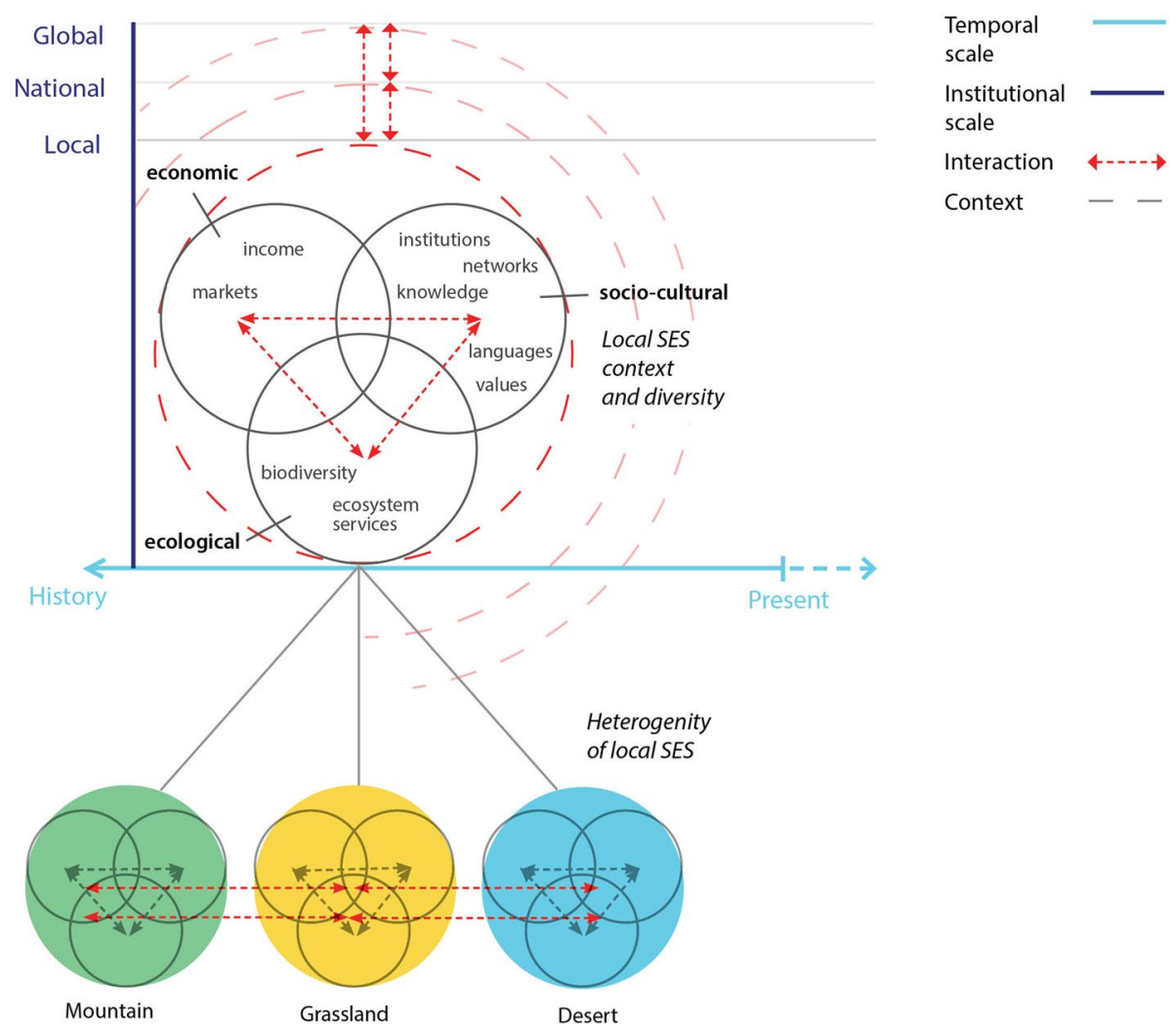

Fig. 1 Any local SES has an economic, ecological and social context that interacts with each other and higher institutional scales over a period of time. The (lack of) management of such cross-scale interactions can affect the resilience of SES. Each individual SES (for example, mountain, grassland and desert) has its own diverse properties, creating heterogeneity of contexts

in Scott 1998; the Northern Highlands Lake District in Walker and Salt 2006) that become incapable of responding to unforeseen shocks (Walker and Salt 2006). A range of different interests, differences in ethnicity (Bardhan and Daton-Johnson 2002) and power imbalances (Reid et al. 2006) can also lead to conflict due to lack of cooperation, and fewer opportunities of implementing shared knowledge (Jordan et al. 2010). Heterogeneity such as locational differences can lead to unequal distribution of resources (Bardhan and DatonJohnson 2002). Cross-scale management can thus incorporate diverse SES traits through the implementation of diverse institutions (Ostrom and Cox 2010) and alter resilience.

\section{Materials and methods}

In this section, we provide a background of the case study region and explain the method of qualitative interviews which was supported by a food plate activity, to understand changes in the agricultural system over time. We analyze direct and indirect drivers of change, which include development interventions as well as the ecological, political and economic contexts. 
Our study investigated interactions at two scales (Fig. 1): (1) Institutional scale-To suit the context of the study, "jurisdictional" scale in Cash et al. (2006) is replaced by institutional scale. (2) Temporal-This scale highlights that SES have their own distinctive histories over which the system develops (Scott 1998; Evans 2004). The aggregation of changes makes a local SES what it is at "present" and defines its future.

\subsection{Case study background}

Sikkim was formerly an independent kingdom and became part of India in 1975. It is situated in the Northeast Himalayas, and home to the Khangchendzonga National Park (KNP), which covers $25 \%$ of its land area. The park harbors a rich biodiversity, including the state symbol-the red panda (ailurus fulgens), and 36 species of rhododendron trees (Sikkim Biodiversity Conservation and Forest Management Project 2012). About 65\% of the population in Sikkim engages in agriculture, which is "undergoing rapid transformation driven by rising globalization, and genetic resources and traditional knowledge are steadily eroding." (2016b:v Sharma et al. 2016). In early 2015, the state was declared as the first fully organic state of India, after having banned the use of chemical fertilizers and pesticides for over ten years.

The central (national) government is considered the highest institutional scale in this study. The state of Sikkim is in the Northeast region of India, under the Ministry of Development of the Northeastern Region. Sikkim is divided into four districts, of which the case study area falls under the West district (Fig. 2). A district is divided into

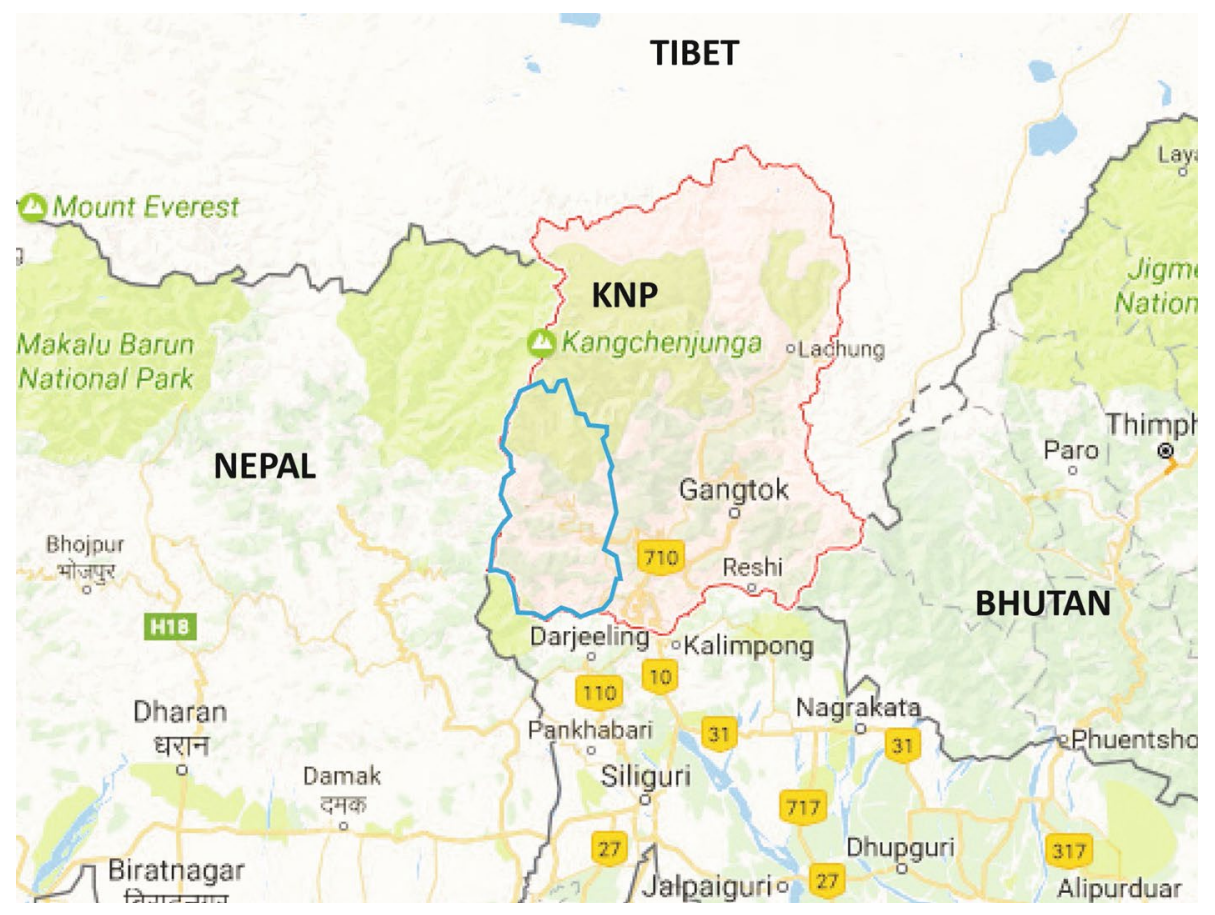

Fig. 2 The field site is located in the West district (blue outline) of Sikkim, close to Khangchendzonga National Park (KNP) and Nepal Source: Google Maps 
"blocks" headed by a block officer, and a block is further divided into Gram Panchayat Units (GPU), which is then further divided into wards. A ward is consequently the lowest scale of this study, headed by a sarpanch or the village head, who is elected by the local people and in theory is responsible to communicate people's needs to the higher levels. A ward may consist of several villages.

The ward chosen for this study is located close to the KNP, near the Eastern border of Nepal (Fig. 2); and the highest village is at an elevation of approximately $3000 \mathrm{~m}$. The population of the ward is less than 300 people (Census of India 2011). The villages are inaccessible by road, thus all social, cultural and economic activities are conducted on foot (Fig. 3). The lifestyle of this mountain community has been shaped by surrounding forests. The first people migrated to Sikkim from Nepal in the early 1900s. The main occupation of the people used to be agropastoralism. Agriculture was mostly practiced for subsistence and pastors used goths (cattle sheds) and hired a gothwala (care-taker) for cattle grazing in the forests. In 1977, their neighboring forest was declared protected under the title of KNP (Maharana et al. 2000). They use the freshwater river as their only source of water and more recently for irrigation. The livelihoods of the people and their relationship with nature have been shaped by development interventions made at different scales by both governmental and non-governmental organizations. The case study area was chosen because of its exceptional remoteness of the region, and the fact that the SES is in a rapid phase of change and development. It provides a unique setup to understand the impact of cross-scale interactions on a local SES.

Fig. 3 Up and down, up and down but mostly up and up. All activities, including heavy head-loading in this mountainous forested region, are conducted on foot. Photograph: R. Gupta

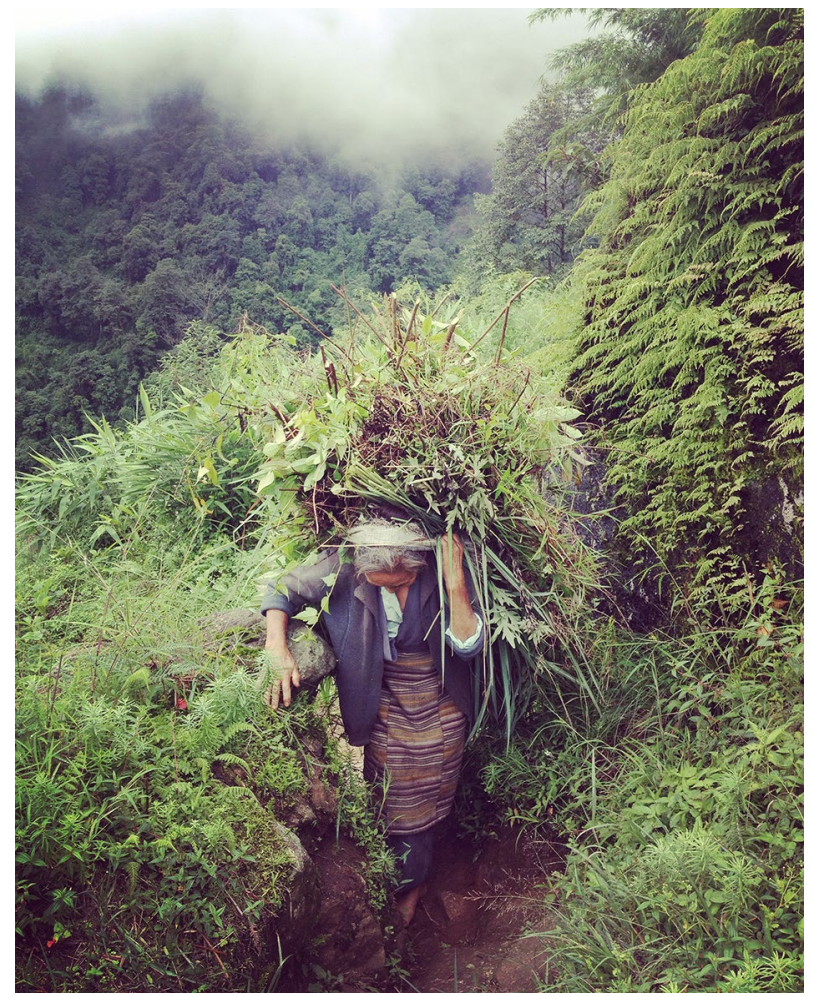




\subsection{Semistructured interviews}

The fieldwork spanned over a period of three weeks in November 2016. Face-to-face interviews were conducted at four different institutional scales (state, district, GPU and ward or local) using a snowball sampling method, of which 15 interviews of respondents (R1-15) (Fig. 4; Appendix 1 Table 5) were used for analyses. For this study, the ward was divided into "upland" and "lowland" based on the difference in altitudes. The upland dwellers gain less profit than those in the lowland due to smaller land holding size and higher head-loading charges of transporting heavy loads over longer distances on foot. The upland region is also incapable of growing the profitable large cardamom spice unlike the lowland due to the difference in temperatures and thus invests in growing vegetables and rearing larger stocks of cattle. The ward name is not disclosed and official government positions are generalized as heads of departments in most cases, in order to maintain anonymity of respondents.

Two sets of semistructured narrative interviews (Kvale 2007) were designed, one for village and another for government actors. Narrative interviews are useful in cases where changes occur over a temporal scale in which past events are linked to the present (Kvale 2007). The aim was to illustrate changes in the local agricultural system over the last 25-30 years along with the perceived drivers of observed changes. This method facilitated collection of narratives at different scales to create a single complex narrative through time, given the different personal experiences of actors interviewed. Here, we acknowledge the possible presence of shifting baselines (Papworth et al. 2009) of individuals.

GOVERNANCE SCALE

Ward
(Local SES) Lowland

FSADD- Department of Food Security \& Agriculture Development HCCD- Department of Horticulture and Cash Crop Development NERLP- North East Rural Livelihood Programme

\section{RESPONDENT(S)}




\subsection{Participatory food plate activity}

A participatory activity was conducted to triangulate information collected during interviews. The aim was to allow participants to collectively recall food habits of the past.

Two teams "A" and "B" were asked to "prepare" a meal from their daily food by illustrating every possible ingredient on a paper that had a pre-illustrated empty "food plate" in the form of a simple circle. The participants had to mark ingredients bought from the market. A suggestion from a team member introduced another marking for items that were sometimes bought from the market but other times grown in their fields.

Both teams discussed what they had "prepared" for the day's meal. The teams were then combined to repeat the steps but this time a meal from as far back as 25-30 years ago was prepared. They then discussed changes in food diets and ranked the top three drivers.

\section{Results}

The local history can be divided into two major demarcations. First, "the merger" of the kingdom of Sikkim with democratic India in 1975, divides the local Sikkimese history into pre-merger and post-merger periods. Second, "the grazing ban," implemented in 2002-2003 in the area of the case study (R1, local scale), divides the local history into a pre- and post-grazing ban periods.

The merger of Sikkim had three major consequences on the local SES. First, Sikkim came under the institutional framework of democratic India and there was a major shift in policies from the past monarchic rule.

"When we were a kingdom, we used to have more [subsistence] agriculture. In my perception, when there was democracy, things changed. By calling people poor, they started giving 'benefits'. Slowly, people started depending on that." (R1, local scale, lowland)

The merger brought new opportunities and opened new markets, thereby increasing external demand for dairy products. This resulted in an overall increase in cattle population in several parts of Sikkim (Tambe and Rawat 2009). Second, post-merger, the old system of patta (tax) on grazing domestic animals and cutting of certain species of trees in the forests, fell out of use. However, it is not clear how strictly regulated the tax system was in the past. Third, the local SES, comprising of villages in the upland and lowland, now came under the jurisdiction of the same ward despite the difference in altitudes.

\subsection{Drivers of change, impacts and outcome}

Besides the historic context, there were three main (sets of) drivers 1-3 that interacted with one another at different scales, causing three major impacts at the local SES (Fig. 5): (I) a shift from subsistence to commercial farming, (II) limited livestock and (III) restricted access to forests. The overall outcome at the local SES is that (a) there is a reduced diversity of food and food sources and (b) the system is becoming increasingly dependent on external food markets and government subsidies. This has resulted in multiple threats to the resilience of the local SES (Table 4). 


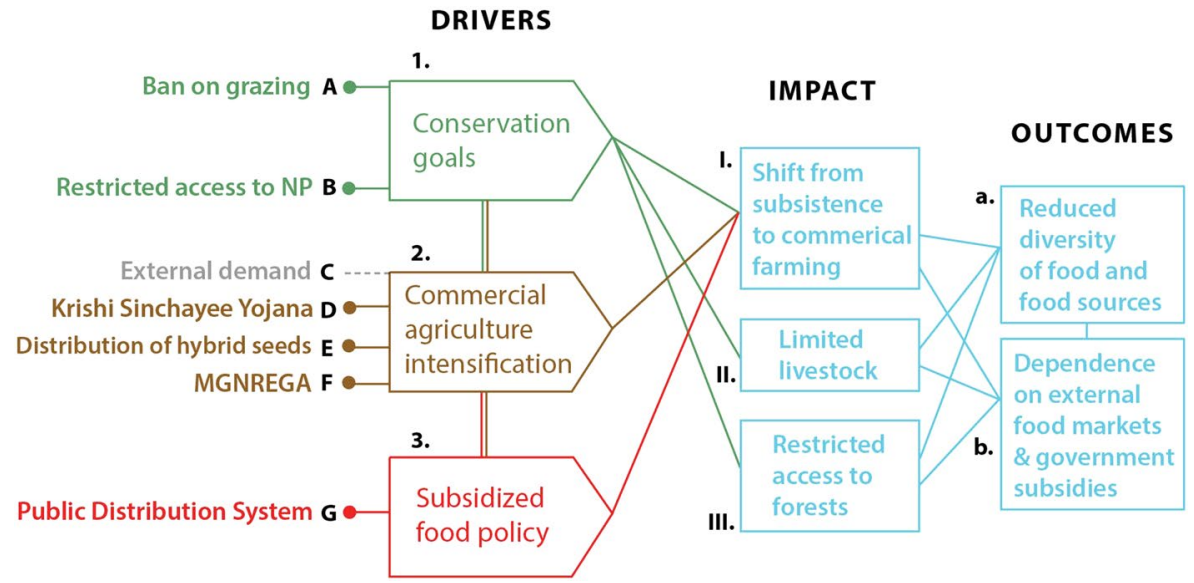

Fig. 5 Drivers that interacted with one another at different scales and caused impacts at the local SES of a shift from subsistence to commercial farming, limited livestock and restricted access to forests. The outcomes are a reduced diversity of food and food sources and dependence on external food markets and government subsidies

\subsubsection{Driver 1: conservation goals}

Policy implications of forest conservation altered traditional livelihoods, which caused outmigration, increased the wild animal population and thus contributed to commercial farming as an alternative to subsistence livelihoods. It also restricted the community's use of forest resources (Fig. 5, 6). Post-merger, the Wildlife Protection Act (1972), became applicable to Sikkim, making it illegal to kill wild animals. According to respondents across every scale, Sikkim is known to be one of the strictest states in implementing conservation-related laws. These steps have potentially increased forest cover, wild animal population, and thus the number of incidences of wild animal interference (mainly eating subsistence crops) according to a majority of interview participants, causing a shift from subsistence to commercial farming. Production of a main staple, phapar (buckwheat), along with ooa (described as similar to wheat by a respondent, R1), took place through the practice of slash and burn. But according to respondents in the lowland, the practice was banned due to risk of forest fires which terminated the production of those crops.

In 1999 the Sikkimese government banned cattle grazing in selective parts of KNP (Tambe and Rawat, 2009). In 2002-2003 the ban was implemented in the region of the case study. The reason for implementing the ban was "serious degradation [of forests]" due to overgrazing (Tambe and Rawat 2009: 95). The immediate effect was a complete loss of the traditional livelihood (Fig. 5) of cattle herding through the gothwala system. The average annual net income previously earned from livestock products such as yak ghee (fat), churpi (cheese), milk, meat and calves by a herder in West Sikkim, dramatically dropped from INR $>25,000$ to INR $<12,000$ post-grazing ban (Bhagwat et al. 2012). This led to outmigration for tourism-related jobs, which meant less helping hands on the farms and a stronger push toward commercial farming (Fig. 6). Consequently, the increased income savings from commercial farming sales potentially increased the trend of outmigration for education and job opportunities outside the villages. Lack of reforms by the government 


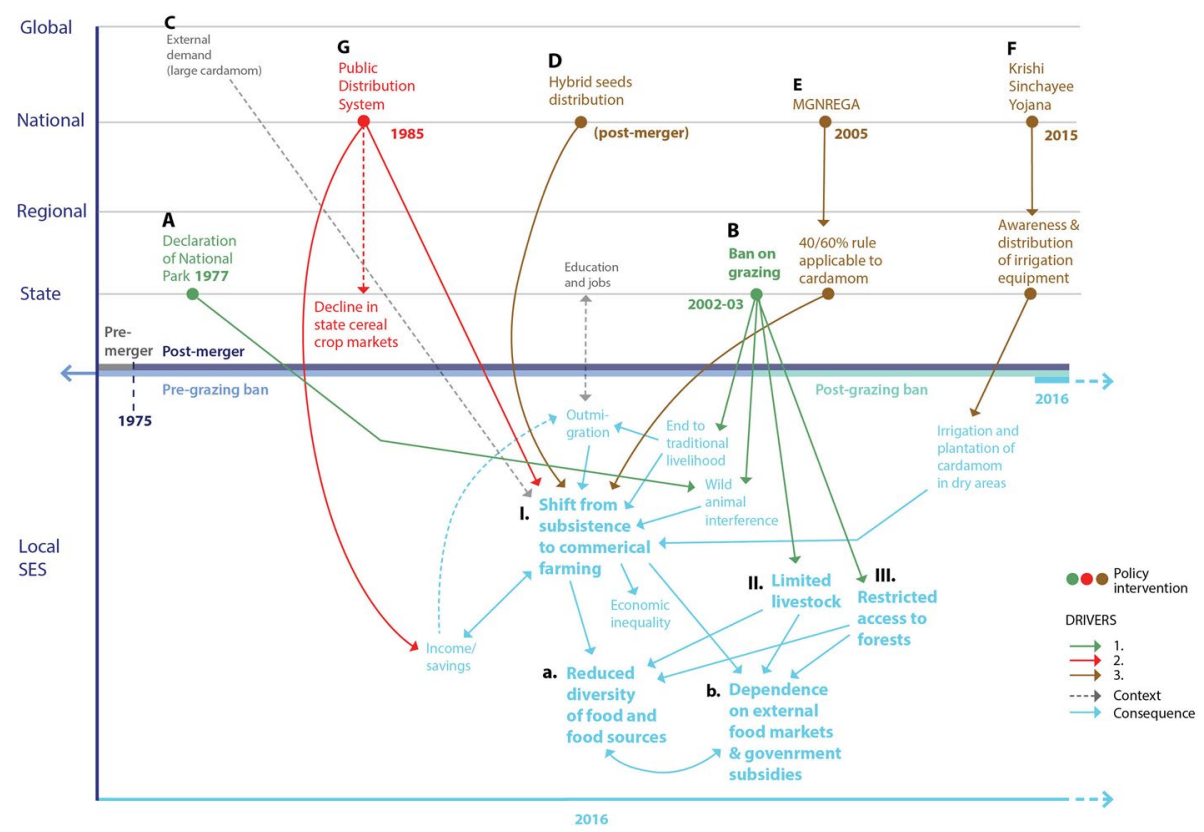

Fig. 6 A representation showing the interactions between cross-scale drivers $(A-G)$ and consequent drivers on an institutional and temporal scale. These brought impacts (I-III) and outcomes (a, b) at the local SES as viewed in 2016

to improve ex-herders' livelihoods post-grazing ban, and its selective and partial nature causes frustration among them even today:

"The government did nothing. We traded 18 yaks. We got Rs. 30,000 and did not get [the remaining] Rs. 81,000 They wrote it on paper. They said after 4 months we will come and give it. But they did not come. This was in 2004. Now we are in 2016." (R5 local scale, upland)

Furthermore, the conservation goals of the Forest Department and conservation NGOs alike do not seem to match the village community's thinking. One of the respondents explains how he is part of a community conservation program and finds himself to be in a difficult position about "protecting" "wildlife":

"On the one hand, I am the protector. For example, I have to save 'wildlife' and 'protect' it. But in turn they come and destroy our agricultural fields." (R1, local scale, lowland)

\subsubsection{Driver 2: commercial agriculture intensification}

The context of external demand (A), policy drivers (B-D), and their interaction contributed to a further shift to commercial farming (Fig. 5). Table 1 summarizes the impacts of the drivers at the local scale. While this shift contributed to farmers' income/savings, it also brought about economic inequality between the upland and lowland (Fig. 6). Post-grazing ban, the lowland has been converting into monocultures of large cardamom, a cash crop, and the upland grows mixed vegetables, which yields less profit. The change in lowland farming has been described as following: 


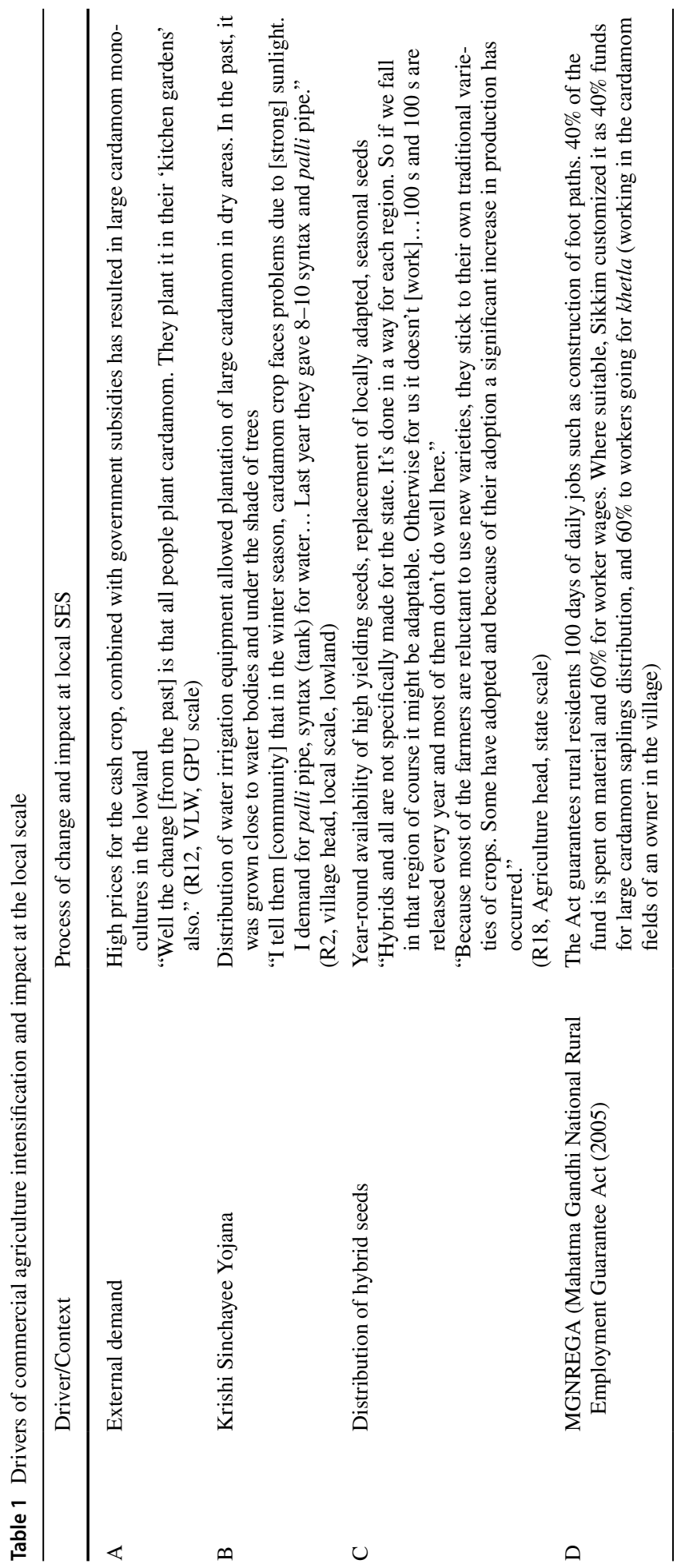


"10 years ago there were less cardamom fields in front of my own eyes. But now there's only cardamom-cardamom. You can't even see houses!” (R1, local scale, lowland)

Coupled with an external demand for large cardamom, government actors described the reasons for this shift to be land and labor shortage, and an increased need for money for education according to local actors.

"With corn, potato and cauliflower one cannot earn money, it is only sufficient for food." (R1, farmer, local scale, lowland)

Drivers B, C, D (Fig. 5, Table 1) are subsidized schemes that have promoted commercial agriculture. The state agriculture head (R18) described them as mandatory from the central government of India. The combination of these subsidies has boosted the growth of large cardamom and replaced other local seeds. A state official argued that:

"It is not us telling them, it is because of the situation... if they see some farmers getting good money from growing cardamom ...bought a car. [Other farmers] will follow." (R19, horticulture head, state scale)

\subsubsection{Driver 3: subsidized food policy}

After the merger, the public distribution system (PDS) was introduced to the local SES from 1985 onward, where below poverty line (BPL) ration cardholders could claim free rice of $35 \mathrm{~kg}$, per family, per month. The policy was recently reformed by the National Food Security Act (NFSA) to allocate $5 \mathrm{~kg}$ of rice for Rs. 3 per family member per month to a new category of Antyodaya Anna Yojana (AAY) cardholders-that makes it possible to include a larger population of poor people who are above the poverty line, yet poor (R16, Food and civil supply head, district scale). Along with the shift to commercial farming (Figs. 5, 6), it impacted the village actors differently because of varied needs and land holding sizes (Table 2). It also competed with the state's cereal crop market (Table 2, Fig. 6). The criteria for selection of AAY cardholders is based explicitly on economic surveys and not the type of crops farmers grow (R16).

Rice was a preferred dietary choice due to its availability and perceived better "taste," but the food in the past was also perceived to be healthier or full of "vitamins" because it was "organic" according to the majority of respondents.

\subsection{Decreased diversity and increased dependence}

The three impacts discussed in previous sections resulted in the outcome (a) reduced diversity of food and food sources and (b) dependence of SES on external food markets and government subsidies (Figs. 5, 6).

The food plate activity illustrates that items bought from the market in the past were mainly salt, rice and chillies. On the other hand, those herders who had smaller land holdings and/or spent more time in the goths, bought items such as rice, wheat and maize either from lowland villages or by loading their pack animals (yaks and horses) once a year in the month of December, from the Geyzing (the capital of West Sikkim) market. This practice has drastically changed since the pre-merger period. Among the top three drivers of change in food diets recognized by lowland and highland activity participants were interference by wild animals, subsidized rice from the government (or availability of rice from markets) and the increase in [external] markets. The ban on slash and burn practice was also described as a major driver by the lowland participants. 


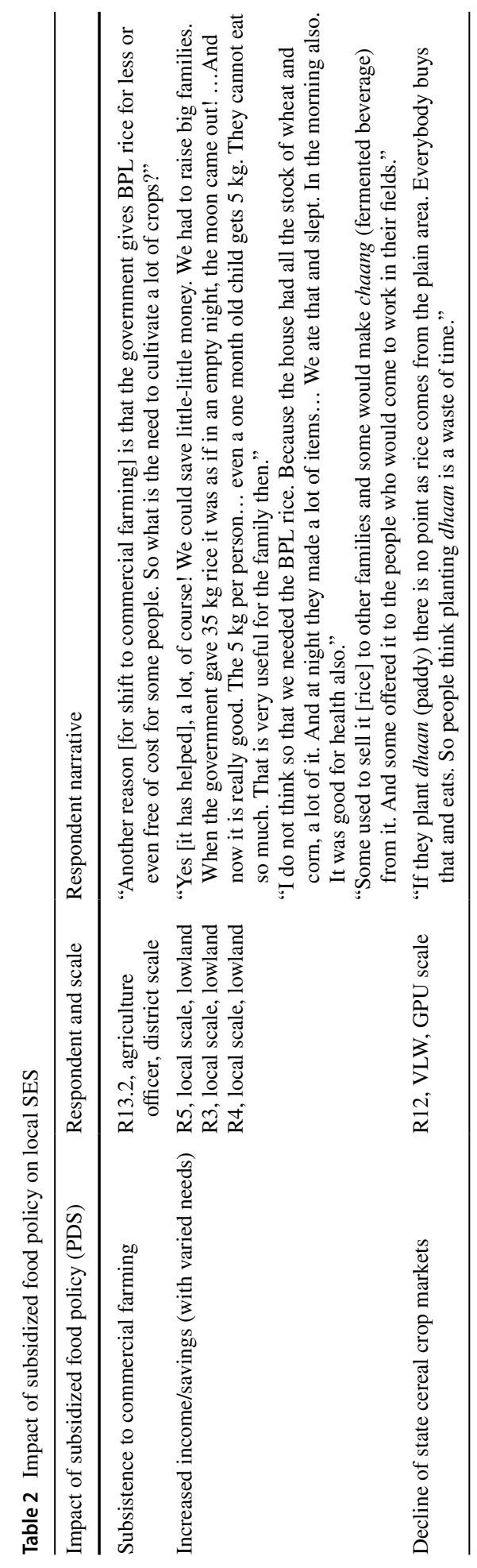


The three main food sources which were identified from the past were subsistence farming, forest foraging and livestock husbandry. They provided a high diversity of foods for people, feed for livestock and manure for subsistence crops, as described in Table 3. It is clear that the three drivers continue to strongly interact and are the main drivers of the decline in diversity. Another important driver that interacted with these three was the rise of external markets and increased income which have made it possible to buy "anything" according to a government actor (R19).

\subsection{Threats to the local SES}

The impacts and outcomes currently result in multiple threats to income and food security of the communities. Respondent narratives around the threats are presented in Table 4. Decisions made based on a snapshot in time may have created more problems and threats rather than eradicating old ones of poverty and lack of roads, a concern for most respondents at the local scale. Disease in large cardamom crops is already bringing lower yields for some farmers, coupled with fluctuating market prices. National insurance for poor farmers covers damages $>40 \%$ to any agricultural crop, due to a natural calamity. Large cardamom falls under the category of horticulture crops, therefore, is not covered in case of an epidemic (R12, GPU scale). This makes livelihoods of those farmers vulnerable, who are now largely dependent on monocultures.

In response to the uncertainty of livelihoods of farmers dependent on large cardamom monocultures, several government actors interviewed, expressed that cardamom cultivation was farmers' own choice and their job as officials was to create awareness and not to impose any particular practice. They also expressed that the traditional integrated system of farming would help farmers to cope with market price fluctuation or diseases, as farmers still maintain a livestock population.

\section{Discussion}

In synthesizing the results of this case study, four main insights emerge. First and second, the case exemplifies "institutional monocropping" and illustrates several instances of institutional misfits. Third, a "global cloud" over the remote region is adding to the region's loss of diversity and vulnerability. Fourth, diversity in and of SES can create resilience, for example, in food systems.

During the pre-merger period, the monarchic rule supported an integrated livelihood system of herding and farming through an access given to the forests, while maintaining a tax on livestock herding. The benefits of dietary diversity obtained from the integrated practice of livestock herding in forests and agriculture are highlighted in a case study from Ethiopia (Baudron et al. 2017). Informal community institutions (Dietz et al. 2003) appear to have played a big role in managing the traditional gothwala system in the forests (examples in Bhasin 2011). It is not known to what extent the tax and informal institutions contributed to ecosystem maintenance and/or if it was meant to exert feudal power. Our interviews clearly suggest that a more diverse food portfolio was consumed traditionally, enabled by a strongly integrated livelihood and diverse production system. Education rates were low, however, and the life as described by several village actors was that of hardship due to the toilsome practice of subsistence agriculture to save up food for the entire year. The personal experience of the horticulture head at the state scale (R19) suggested a positive shift in economy and thus a higher standard of living across remote villages in Sikkim. 


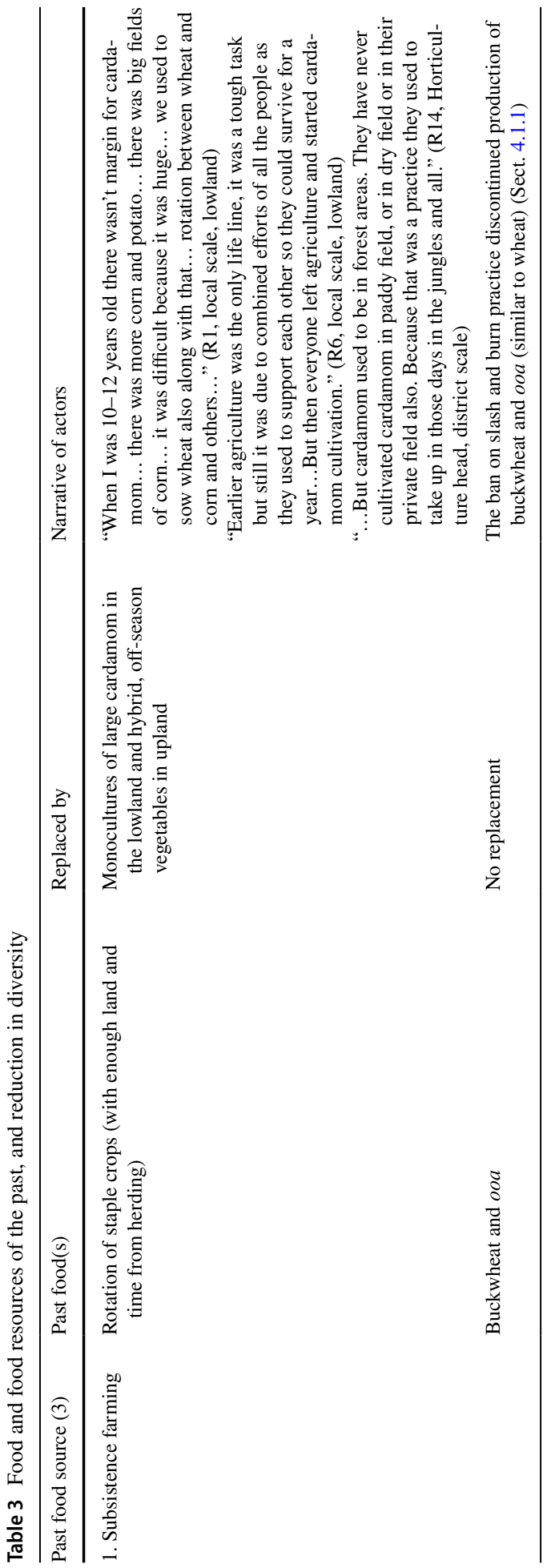




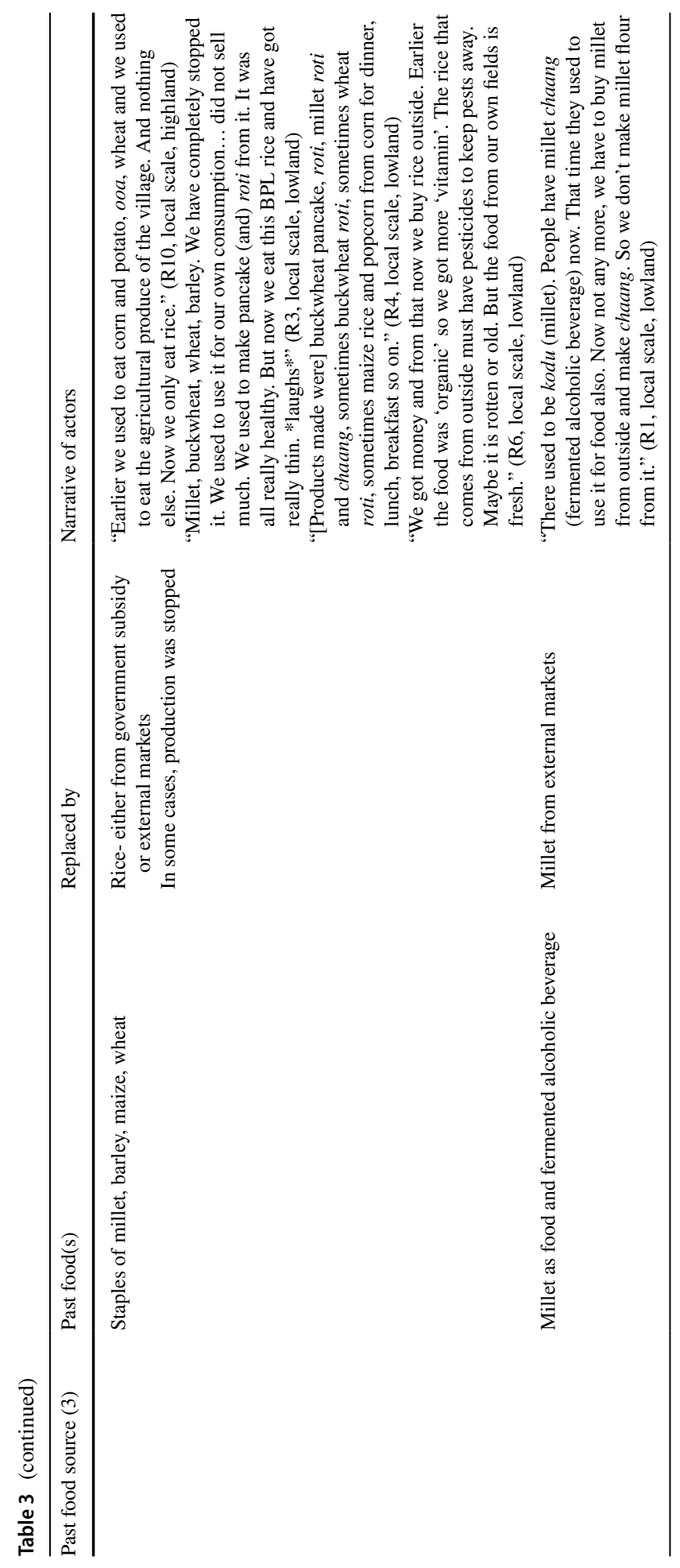




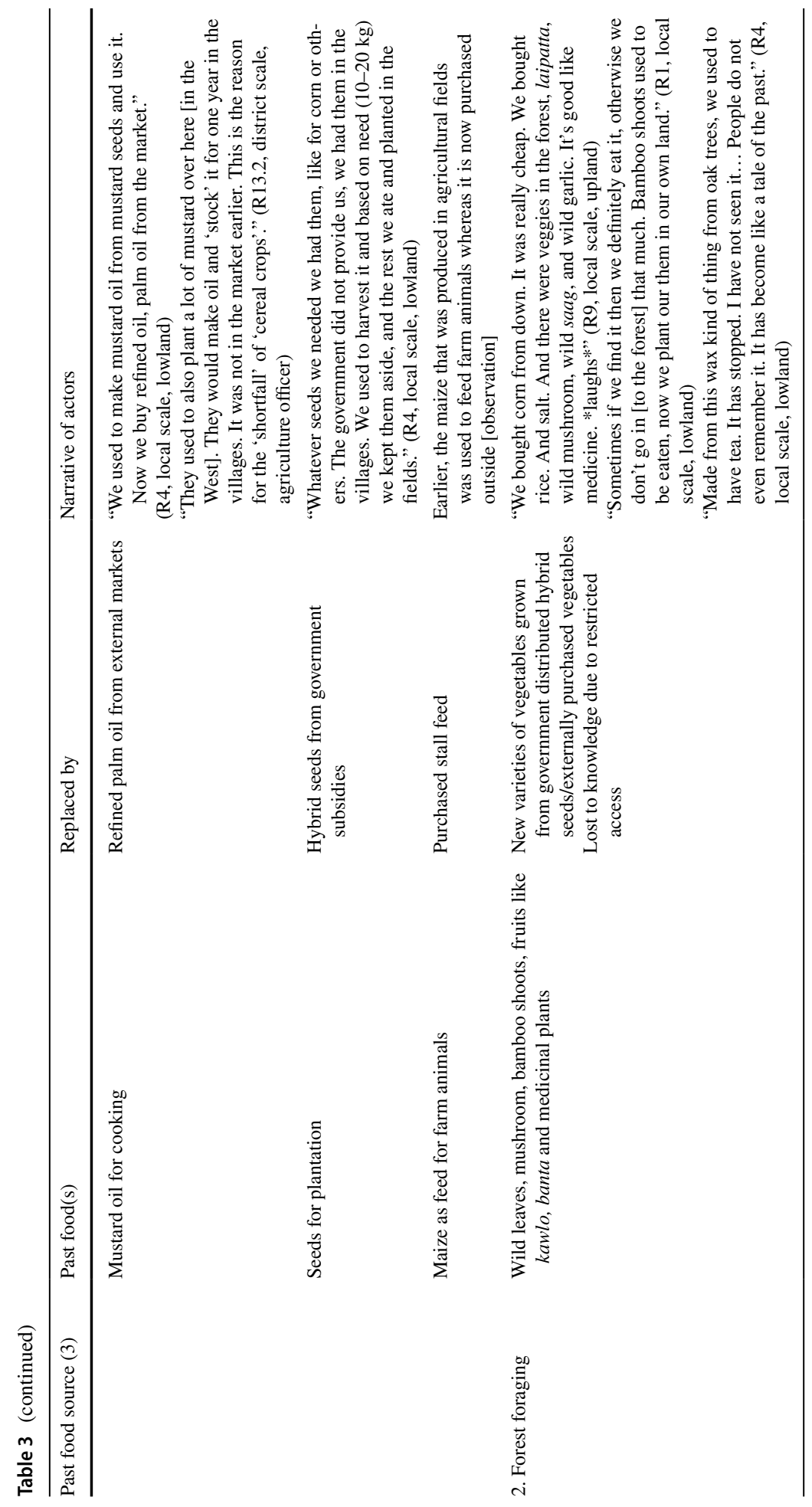




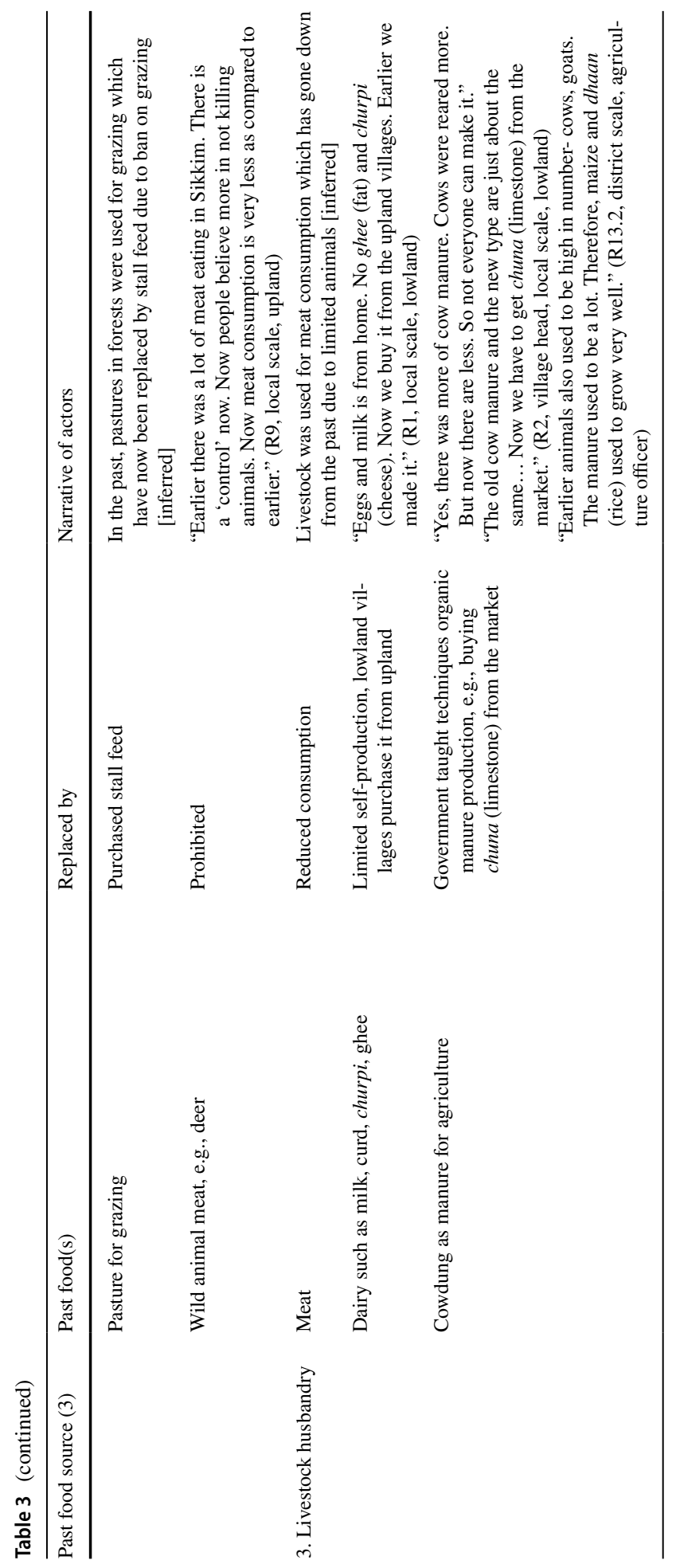




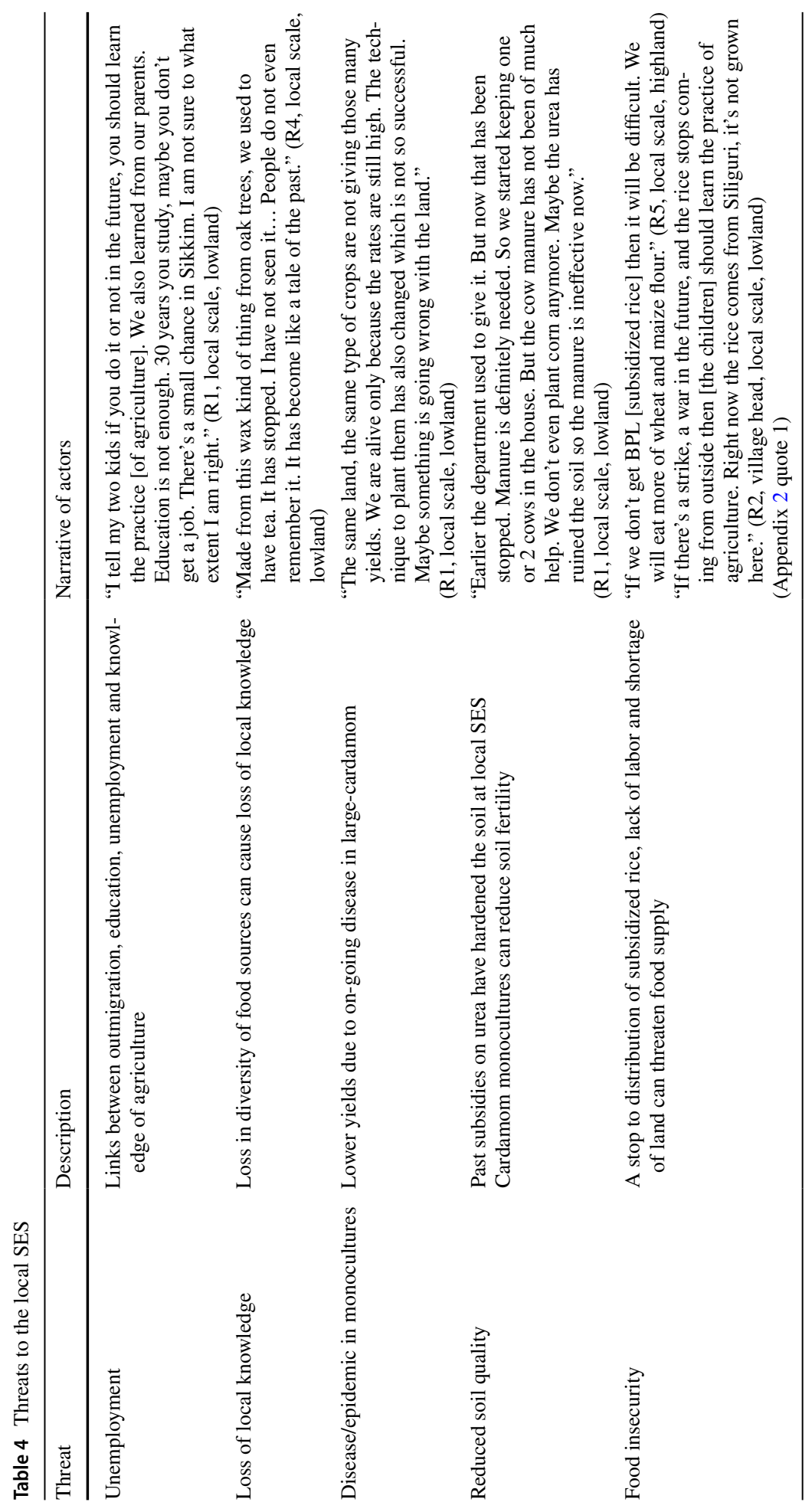




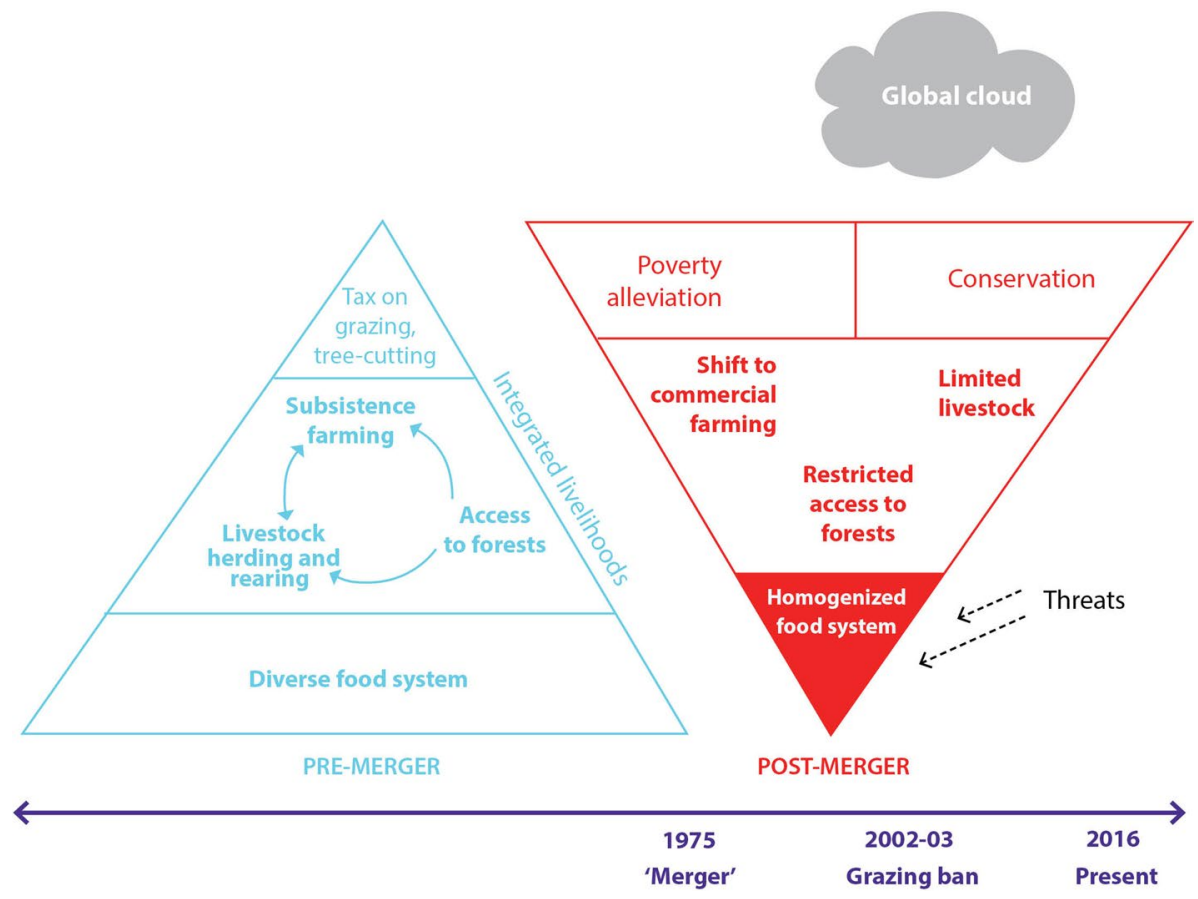

Fig. 7 From an integrated livelihood system during monarchic rule which provided a diverse portfolio of food, to separation of these systems due to parallel focus on poverty alleviation and conservation during the post-merger period, causing the "diversity triangle" to reverse and homogenize the food system. These changes were brought in synergy with a "global cloud"

Post-merger policies and the influence of the "global cloud" (Sect. 5.3) have weakened the integrated livelihood practice over time, homogenizing and threatening the food system (Sects. 4.2, 4.3) by reversing the old "diversity triangle" (Fig. 7). Certain measures for poverty alleviation for the local SES were not differentiated from rest of Sikkim or the Indian subcontinent. The case re-emphasizes a lack of mountain perspective in development strategies in India (Maikhuri et al. 2001). The results indicate that local history, social-ecological context, and effects of cross-scale interactions need consideration for policy implementation.

\subsection{A case of institutional monocropping}

The overall policy approach concerning agriculture, food and forests fails to draw links between its resources, and the diversity of needs among geographically and historically different local SES where policy implementation occurs (Appendix 2 quote 2, Sects. 4.1, 4.2). Such an approach has been termed as "institutional monocropping" by Evans (2004).

Agriculture schemes were mandatorily implemented leading to economic inequality between the lowland and upland communities. This is a problem associated with intensification due to inequitable distribution of market opportunities (Carswell 1997). The step to ban grazing has adversely affected the upland communities due to smaller land holding size and non-suitable climate to grow pricey commercial crops. While bringing inequality, the policy context is also replacing communities' individual practices with the same type of knowledge, due to a shift in food diets (Table 3). 


\subsection{A case of misfits}

Our study recognizes that policies shift focus to commercial agriculture as it contributes to income security of farmers. A shift in focus of policy is inevitable with changes in global economy Pingali (1997). However, in this case, the separation of social and ecological components for poverty alleviation and conservation goals in the post-merger period (Fig. 7) has led to several institutional misfits. The following four examples from the case study illustrate why the needs of diverse local SES should not be generalized.

First, Sikkim recently launched the Organic Mission programme, by certifying farmers' agricultural produce as completely chemical free. It is ironic since the farmers themselves are consuming rice as their main staple, supplied from external sources for PDS (subsidized food policy). The ban on grazing restricts manure production from cow dung which is essential for organic farming, making production output a greater challenge (Chakrabarti 2011). The recent Mission Organic Value Chain Development (MOVCD) has notified turmeric, large cardamom, ginger and buckwheat for export sales. Three out of four are cash crops, of which buckwheat production has stopped in the local SES (Sect. 4.1.1., Table 3). This increases the incentive to grow cash crops and buy food from external markets.

Second, the PDS was started in the 1940s during the British colonial rule of India to which many reforms were made after India's independence (Mooij 1998). Sikkim came directly under this policy post-merger, while the case study shows that there was a difference in needs of people (Table 2). The subsidy discounted what the communities used to grow for self-consumption (rice does not grow in high altitude regions). In a similar case in the Central Himalayas, the PDS has caused a loss of traditionally grown crops (Maikhuri et al. 2001).

Third, the conservation goals have come in direct collision with the relationship between local communities and their environment. There were no steps taken after the ban on grazing to improve the livelihoods of the herders. The community conservation program, set up by NGOs in collaboration with the Forest Department, appears to be an imposed view of what "conservation" means (Sect. 4.1.1).

There is a lack of evidence that justifies the step of a complete ban on grazing in selective sites or its success so far. A government document (Forests, Environment \& Wildlife Management Department, 2010: 1) describes the "age old system of grazing" to be a "menace and nuisance" and that the ban has revived "sick and dying lakes" due to increased cattle population and consequent forest degradation. None of the reports (see Tambe et al. 2005) or academic papers (see Singh et al. 2003; Tambe and Rawat 2009) clarify if the local herders were consulted. This is a common case of excluding lower scales in environmental assessments (Reid et al. 2006). An ex-herder and elder of the village, had strongly disagreed with the logic behind the ban, claiming that grazing helped maintain moisture in the soil (Appendix 2 quote 3) (R5, local scale upland).

Fourth, the conservation goals have pushed the system to intensify commercial agriculture, which requires land for the increasing cardamom monocultures and other commercial farming. This is a paradox as global demand for agriculture is in collision with the conservation goals (Lambin and Meyfroidt 2011; Sayer et al. 2013). Sikkim, being a mountain state, faces the challenge of land shortage and increased pressure from urbanization and infrastructure development (a concern expressed several times by government officials), contributing to Sikkim's existing food deficit situation (Food Security \& Agriculture Development Department 2011).

\subsection{The global cloud over the remote local SES}

The large cardamom monocultures are being driven by potential global markets and state efforts to connect with the markets (Table 1, Kumar 2016) through existing national 
government schemes. Sikkim contributes to $88 \%$ of India's large cardamom production and is the second largest exporter of the crop in the world after Nepal (Sharma et al. 2016a). Monocultures and corresponding lack of diversity have serious ecological and economic implications (Table 4) which can create "gilded traps" (Steneck et al. 2011). The trend of integration of rural agriculture with global markets is on the rise (Mikulcak et al. 2015). The replacement of subsistence foods with imported market products reflects "distancing" (Lambin and Meyfroidt 2011), causing a disconnect between diets and food sources at a global scale (Gordon et al. 2017). We term these distant global influences on the local SES as the "global cloud."

Outmigration of younger populations is another trend in developing countries (Hazell and Wood 2007), which was given a push by the ban on grazing in the case study. The high rates of unemployment among the youth of Sikkim (Government of Sikkim 2015), is yet another paradox since education and job opportunities are the main reason for outmigration to urban towns.

In 2015 World Bank provided funding to the northeast Indian regional ministry for the North East Rural Livelihood Project (NERLP), to distribute funds to "self-help groups". Their aim is to enhance on-going activities within the guidelines of World Bank, by collaborating with government departments and NGOs (R15, district scale). This intervention poses questions for providing social funds to communities for economic growth based on the present situation and potentially contributing to unsustainable practices such as that of the monocultures. World Bank and similar organizations have been heavily criticized for similar unsustainable outcomes (Young 2002).

\subsection{Resilience in diversity: local to global concerns}

In this section, we take excerpts from the case study to tie-in global-scale concerns in relation to diversity of food. Past food sources at the local SES have drastically diminished, reducing the intake of diverse foods. Dietary diversity loss can reduce micronutrient adequacy (Steyn et al. 2006). The distribution of hybrid seeds along with warmer climate has made vegetable production viable in the uplands which was not possible in the past. This can be viewed as increased diversity. While the increasing availability of products in the nearest markets also point to increased diversity (for example, Dame and Nüsser's 2011 case study in Ladakh), it demands an increased and stable monetary income and replaces subsistence foods (Table 3).

In the lowlands, kitchen gardens have become smaller in size and replaced by cardamom monocultures. Similar trends of decline in traditional crops have been attributed to the introduction of hybrid seeds and commercial farming in neighboring countries of Pakistan, Bhutan, Afghanistan, Nepal and Bhutan (discussed in Maikhuri et al. 2001). This is worrying because an increasing genetic uniformity gives rise to monopoly, threatening the resilience of food supply (Walker and Salt 2006).

Forest foraging (Table 3) contributed not only to fodder for livestock growth (which provides a wide range of variety of protein-rich foods and meat) but also provided wild foods. Highly nutritious foods obtained from biodiversity are being replaced by globally marketed foods which are energy rich but less nutritious (Romanelli et al. 2015). Serious concerns exist for the homogenization of agriculture through the adoption of uniform crops across the world (Carswell 1997) which threatens agrobiodiversity and the knowledge associated with it (Maikhuri et al. 2001). The 2030 agenda acknowledges that both natural and cultural diversity is contributors to meet the Sustainable Development Goals (United Nations General Assembly 2015).

Cross-scale interactions are increasingly acknowledged in the literature associated with social-ecological systems (Liu et al. 2015b) as well as sociohydrological systems (Pande 
and Savenije 2016; Pande and Sivapalan 2016). Our case study is a step toward illustrating the outcomes of such interactions as observed by respondents of this study and the associated literature. Although multiple interactions were observed, this study is only an indication of how the many mechanisms operate in social-ecological systems. We show how such interactions can be understood and visualized. Further development of theory, methods and empirical case studies will help develop an understanding of how such interactions can be governed to meet the needs of local communities on a connected planet.

\section{Conclusion}

The aim of this study was to understand the influence of cross-scale interactions on a local SES in Sikkim by observing changes in its agricultural system. The results suggest that despite its remote location, the SES is highly influenced by higher scales. The integrated livelihood practice is being eroded over time, at the hands of uniform development goals, making the system highly vulnerable to shocks. The vulnerability arises due to homogenization of food sources and an increased dependence on external markets and government subsidies for food and income. Future studies should focus on assessing nutritional changes with relation to trends of foods obtained from agriculture, livestock, forests and markets.

Economic inequality between the lowland and upland communities has emerged due to a failure to address diverse needs. Acknowledging diversity of individual SES emerges as a key factor for consideration during management. A one-size-fits-all approach (Ostrom and Cox 2010) can lead to misfits at local scales. The case study has broader implications, suggesting that policy interventions that aim to optimize natural resources for shortterm gains and reduce diversity in ecosystems (Walker and Salt 2006). This process can be facilitated further if policies act in synergy with one another (Bunce et al. 2010) and "global clouds" to eliminate options at a local SES. The amplified result could be a threat to global resilience (Cash et al. 2006) due to a loss of social-ecological diversity, as local processes influence global SES through summation (Gallopin 1991). Thus, an understanding of such cross-scale dynamics can greatly inform long-term development goals. As a first step, a participatory scenario planning exercise (Oteros-Rozas et al. 2015), while comparing diverse needs of lowland and upland residents, could greatly contribute to cross-scale management for desirable futures of food and livelihoods at the local SES.

Acknowledgements We would like to express our endless gratitude to all the respondents of our study for their time and support. The study was funded by Mistra through a core grant to Stockholm Resilience Centre, and the GRAID program, funded by Sida. This study was built on a master's thesis at the Stockholm Resilience Centre.

OpenAccess This article is distributed under the terms of the Creative Commons Attribution 4.0 International License (http://creativecommons.org/licenses/by/4.0/), which permits unrestricted use, distribution, and reproduction in any medium, provided you give appropriate credit to the original author(s) and the source, provide a link to the Creative Commons license, and indicate if changes were made.

\section{Appendix 1}




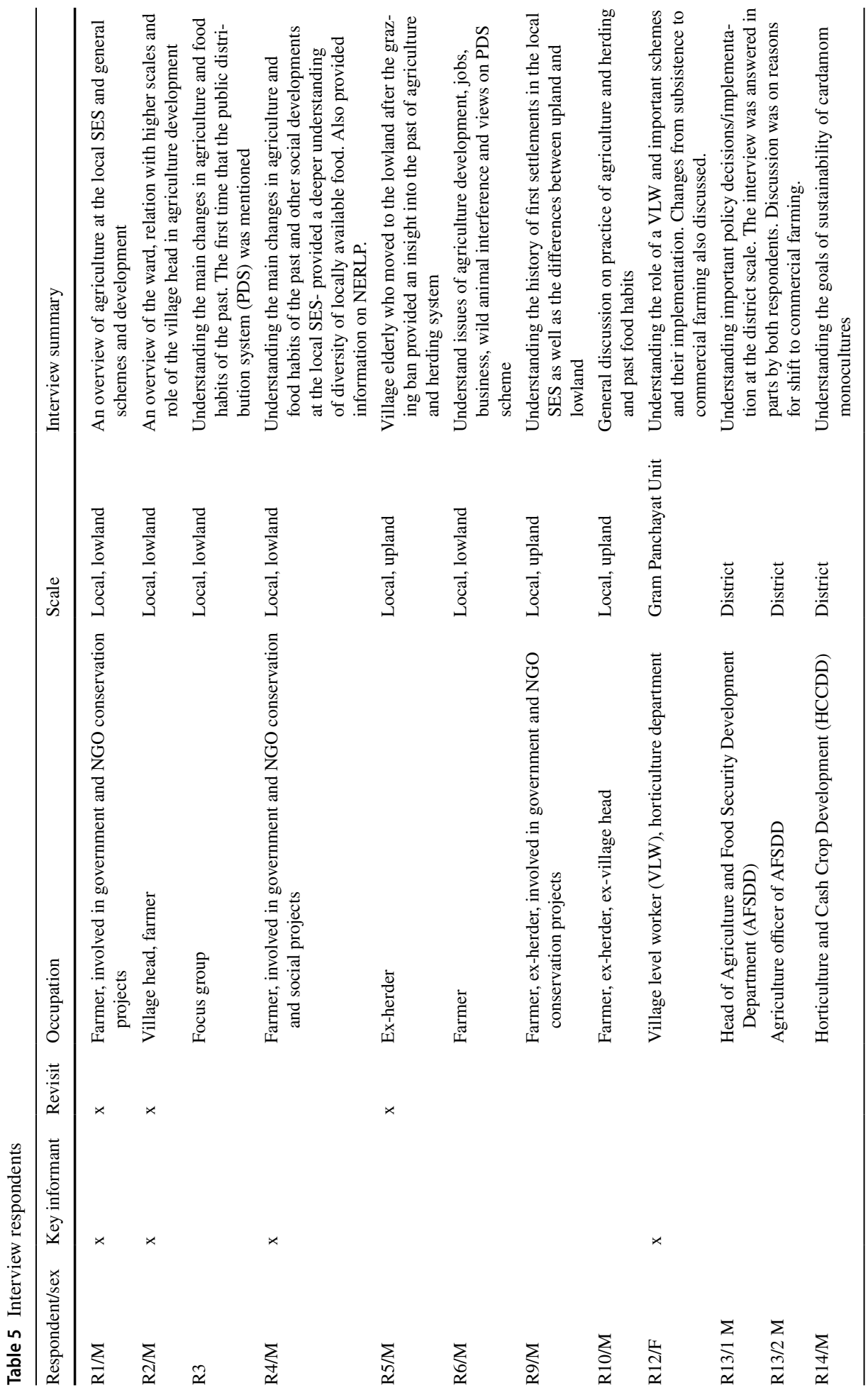




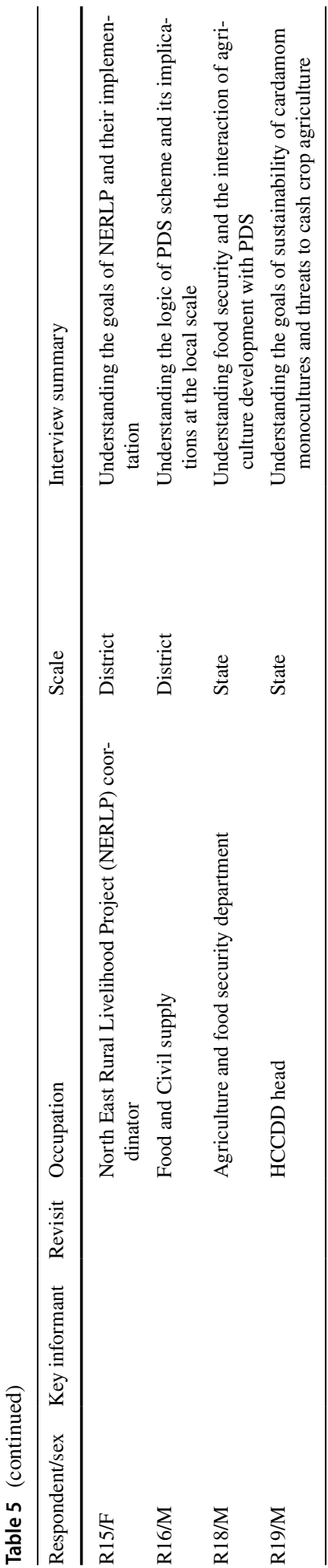

Springer 


\section{Appendix 2: Quotes}

Quote 1: "Food security we may have a bit problem... Sustainability in cereal crops [is] definitely [needed], because our land holdings are decreasing every day." (R18, agriculture head, state scale)

Quote 2: "Now farm mechanization is also one of the important things. If you see European countries, who is rich? Farmers are rich. Because the whole cultivation practice is through mechanization... then less labor is needed. Then unemployed, educated youth can also sit at home, start doing his cultivation through computers. Just put the tie, boot, suit... Who will work? The machines will work." (R14, Horticulture head, district scale)

Quote 3: "They said the forest is getting finished. They said the yaks go there, graze the land and drink water. It has to be closed. Now the water has dried out. The jungle gets thorny. The yaks used to clear everything. They loosen the soil by digging it out. Now the water cannot gather in those spots. It has dried out. The animals went up in numbers, for example, bears. The path has become full of stones." (R5, local scale, upland)

\section{References}

Adger, W. N., Brown, K., \& Tompkins, E. L. (2006). The political economy of cross-scale networks in resource co- management. Ecology and Society, 10(2), 9.

Anonymous. (2015). European Commission. Retrieved October 12, 2017 from http://forobs.jrc.ec.europ a.eu/products/gam/.

Bardhan, P., \& Dayton-Johnson, J. (2002). Unequal Irrigators: Heterogeneity and Commons Management Large-Scale Multivariate Research. In E. Ostrom, T. Dietz, N. Dolsak, P. C. Stern, S. Stonich, \& E. U. Weber (Eds.), The drama of the commons (pp. 87-112). Washington, D.C: National Academy Press.

Baudron, F., Duriaux Chavarría, J.-Y., Remans, R., Yang, K., \& Sunderland, T. (2017). Indirect contributions of forests to dietary diversity in Southern Ethiopia. Ecology and Society, 22(2), 28.

Berkes, F. (2002). Cross-scale institutional linkages: Perspectives from the bottom up. In E. Ostrom, T. Diez, N. Dolsak, P. C. Stern, S. Stonich, \& E. U. Weber (Eds.), The drama of the commons (pp. 293321). Washington, D.C., USA: National Academy Press.

Bhagwat, S., Diwan, M., \& Venkataramani, V. (2012). Study of ecological and socio-economic and livelihood: Dimensions of grazing exclusion in protected forests of West Sikkim. Unpublished report. http:// www.sikkimforest.gov.in/Grazing-ban-study.htm.

Bhasin, V. (2011). Pastoralists of Himalayas. Journal of Human Ecology, 33(3), 147-178.

Brown, K. (2003). Integrating conservation and development: A case of institutional misfit. Frontiers in Ecology and the Environment, 9(3), 479-487.

Bunce, M., Brown, K., \& Rosendo, S. (2010). Policy misfits, climate change and cross-scale vulnerability in coastal Africa: How development projects undermine resilience. Environmental Science \& Policy, 13(6), 485-497.

Carswell, G. (1997). Agricultural intensification and rural sustainable livelihoods: A "think piece." IDS Working Paper (64):30.

Cash, D. W. (2006). Scale and cross-scale dynamics: Governance and information in a multilevel world. Ecology and Society, 11(2), 8.

Census of India. (2011). Sikkim, district census handbook: North, West, South and East districts. Village and Town wise, Primary Census Abstract. 12 XII-B:283. Gangtok, Sikkim.

Chakrabarti, A. (2011). Transhumance, Livelihood and Sustainable Development and Conflict between Formal institution and Communal Governance: An Evaluative Note on East Himalayan State of Sikkim, India. International Conference on Social Science and Humanity IPEDR, 5, 1-7. 
Crutzen, P. J. (2006). The "Anthropocene". In E. Ehlers \& T. Krafft (Eds.), Earth system science in the anthropocene (pp. 13-18). Berlin, Heidelberg: Springer.

Dame, J., \& Nüsser, M. (2011). Food security in high mountain regions: Agricultural production and the impact of food subsidies in Ladakh. Northern India. Food Security, 3(2), 179-194.

Dietz, T., Ostrom, E., \& Stern, P. C. (2003). The Struggle to Govern the Commons. Science, 302(5652), $1907-1912$.

Evans, P. (2004). Development as institutional change: The pitfalls of monocropping and the potentials of deliberation. Studies in Comparative International Development, 38(4), 30-52.

Folke, C., Carpenter, S., Walker, B., Scheffer, M., Chapin, T., \& Rockström, J. (2010). Resilience thinking: Integrating resilience, adaptability and transformability. Ecology and Society, 15(4), 20. http://www. ecologyandsociety.org/vol15/iss4/art20/.

Folke, C., Pritchard, L., Berkes, F., Colding, J., \& Svedin, U. (2007). The problem of fit between ecosystems and institions: Ten years later. Ecology and Society, 12(1), 30.

Food Security \& Agriculture Development Department, Government of Sikkim. (2011). Annual Progress Report 2010-11. Available online at: http://sikkimagri.gov.in/General/UploadedFiles/Downloads/12. pdf.

Forests, Environment \& Wildlife Management Department, Government of Sikkim. (2010). Schemes and Policies implemented from 1995-1996 till 2010-2011. Available online at: http://www.sikkimfore st.gov.in/Reports\%20and\%20Publications/15years/11_Chapter\%20II\%20Ban\%20on\%20Grazing\%20 pg\%2031-32.pdf.

Galaz, V., Olsson, P., Hahn, T., Folke, C., \& Svedin, U. (2008). The problem of fit among biophysical systems, environmental and resource regimes, and broader governance systems: Insights and emerging challenges. In O. R. Young, L. A. King, \& H. Schroeder (Eds.), Institutions and environmental change: Principal findings, applications, and research frontiers (pp. 147-186). Cambridge: The MIT Press.

Gallopin, G. C. (1991). Human dimensions of global change: Linking the global and local processes. International Social Science Journal, 130, 707-718.

Gordon, L. J., Bignet, V., Crona, B., Henriksson, P. J. G., Van Holt, T., Jonell, M., et al. (2017). Rewiring food systems to enhance human health and biosphere stewardship. Environmental Research Letters, 12(10), 100201.

Government of Sikkim. 2015. Sikkim Human Development Report. (2014). Expanding opportunities, promoting sustainability. New Delhi, India: Routledge.

Hazell, P., \& Wood, S. (2007). Drivers of change in global agriculture. Philosophical Transactions of the Royal Society B: Biological Sciences, 363(1), 495-515.

Jordan, A., Huitema, D., Rayner, T., \& Van Asselt, H. (2010). Governing the European Union: Policy choices and governance dilemmas. In A. Jordan, D. Huitema, H. Van Asselt, T. Rayner, \& F. Berkhout (Eds.), Climate change policy in the European Union: Confronting the dilemmas of mitigation and adaptation? (pp. 29-51). Cambridge: Cambridge University Press.

Kotschy, K., Biggs, R., Daw, T., Folke, C., \& West, P. (2015). Principle 1: Maintain diversity and redundancy. In R. Biggs, M. Schluter, \& M. Schoon (Eds.), Principles for building resilience: Sustaining ecosystem services in social-ecological systems (pp. 50-79). Cambridge: Cambridge University Press.

Kumar, V.S. (2016). The Hindu. Retrrieved 10 November, 2017, from https://www.thehindubusinessline .com/economy/agri-business/demand-for-large-cardamom-to-rise-spices-board/article8151438.ece.

Kvale, S. (2007). Doing interviews. Thousand Oaks, CA: Sage.

Lambin, E. F., \& Meyfroidt, P. (2011). Global land use change, economic globalization, and the looming land scarcity. Proceedings of the National Academy of Sciences, 108(9), 3465-3472.

Liu, Z., \& Alexander, M. (2007). Atmospheric bridge, oceanic tunnel, and global climatic teleconnections. Reviews of Geophysics, 45, RG2005. https://doi.org/10.1029/2005rg000172.

Liu, J., Hull, V., Luo, J., Yang, W., Liu, W., Viña, A., et al. (2015a). Multiple telecouplings and their complex interrelationships. Ecology and Society, 20(3), 44.

Liu, J., Mooney, H., Hull, V., Davis, S. J., Gaskell, J., Hertel, T., et al. (2015b). Systems integration for global sustainablity. Science, 347(6225), 1258832-1-1258832-9.

Ludwig, D., Hilborn, R., \& Walters, C. (1993). Uncertainty, resource exploitation, and conservation: Lessons from history. Science, 260(17), 36.

Maharana, I., Rai, S. C., Chettri, N., \& Sharma, E. (2000). Fuelwood pressure on the natural forests of Khangchendzonga National Park of Sikkim Himalaya. In A. Arunachalam \& M. L. Khan (Eds.), Sustainable management of forests-India (pp. 279-295). Dehradun: International Book Distributors.

Maikhuri, R. K., Rao, K. S., \& Semwal, R. L. (2001). Changing scenario of Himalayan agroecosystems: Loss of agrobiodiversity, an indicator of environmental change in Central Himalaya. India. The Environmentalist, 21(1), 23-39. 
Mikulcak, F., Haider, J. L., Abson, D. J., Newig, J., \& Fischer, J. (2015). Applying a capitals approach to understand rural development traps: A case study from post-socialist Romania. Land Use Policy, 43, 248-258.

Mooij, J. (1998). Food policy and politics: The political economy of the public distribution system in India Food Policy and Politics: The Political Economy of the Public Distribution System in India. The Journal of Peasant Studies, 25(2), 77-101.

Ostrom, E., \& Cox, M. (2010). Moving beyond panaceas: A multi-tiered diagnostic approach for socialecological analysis. Environmental Conservation, 37(4), 451-463.

Oteros-Rozas, E., Martín-López, B., Daw, T., Bohensky, E. L., Butler, J., Hill, R., et al. (2015). Participatory scenario planning in place-based social-ecological research: Insights and experiences from 23 case studies. Ecology and Society, 20(4), 32. https://doi.org/10.5751/ES-07985-200432.

Pande, S., \& Savenije, H. H. G. (2016). A socio-hydrological model for smallholder farmers in Maharashtra, India. Water Resources Research, 52, 1923-1947. https://doi.org/10.1002/2015WR017841.

Pande, S., \& Sivapalan, M. (2016). Progress in socio-hydrology: A meta-analysis of challenges and opportunities. Wiley Interdisciplinary Reviews: Water 4(4).

Papworth, S. K., Rist, J., Coad, L., \& Milner-Gulland, E. J. (2009). Evidence for shifting baseline syndrome in conservation. Conservation Letters, 2, 93-100.

Pingali, L. P. (1997). From subsistence to commerical prodcution systems: The Transformation of Asian Agriculture. American Journal of Agricultural Economics, 79(2), 628-634.

Reid, W. V., Berkes, F., Wilbanks, T., \& Capistrano, D. (2006). Bridging scales and knowledge systems. Washington, DC: Millennium ecosystem assessment and Island Press.

Romanelli, C., Cooper, D., Campbell-Lendrum, D., Maiero, M., Karesh, W.B., Hunter, D., \& Golden, C. D. (2015). Connecting global priorities: Biodiversity and human health, a state of knowledge review. Page World Health Organization and Secretariat for the Convention on Biological Diversity. WHO Library Cataloguing-in-Publication Data. https://www.cbd.int/health/SOK-biodiversity-en.pdf.

Sayer, J., Sunderland, T., Ghazoul, J., Pfund, J.-L., Sheil, D., Meijaard, E., et al. (2013). Ten principles for a landscape approach to reconciling agriculture, conservation, and other competing land uses. Proceedings of the National Academy of Sciences, 110(21), 8349-8356.

Scott, J. C. (1998). Seeing like a state. New Haven: Yale University Press.

Sharma, G., Partap, U., Dahal, D. R., Sharma, D. P., \& Sharma, E. (2016a). Declining Large-Cardamom Production Systems in the Sikkim Himalayas: Climate Change Impacts, Agroeconomic Potential, and Revival Strategies. Mountain Research and Development, 36(3), 286-298.

Sharma, G., Partap, U., Sharma, E., Rasul, G., Awasthe, R. K. (2016b). Agrobiodiversity in the Sikkim Himalaya: Sociocultural significance, status, practices, and challenges. ICIMOD Working Paper No. 2016/5.

Sikkim Biodiversity Conservation and Forest Management Project. (2012). Sikkim Biodiversity Action Plan. Forests Environment and Wildlife Management Department, Government of Sikkim. Gangtok, Sikkim. Available online at: http://www.sikenvis.nic.in/PublicationDetails.aspx?SubLinkId=134\&LinkI $\mathrm{d}=2662 \&$ Year $=2014$.

Singh, B. H., Sundriyal, R. C., \& Sharma, E. (2003). Livestock grazing in the Khangchendzonga Biosphere Reserve of Sikkim Himalaya, India: Implications for Management. Indian Forester, 129(5), 611-623.

Steneck, R. S., Hughes, T., Cinner, J., Adger, W., Arnold, S., Berkes, F., et al. (2011). Creation of a gilded trap by the high economic value of the Maine lobster fishery. Conservation Biology, 25, 904-912.

Steyn, N. P., Nel, J. H., Nantel, G., Kennedy, G., \& Labadarios, D. (2006). Food variety and dietary diversity scores in children: Are they good indicators of dietary adequacy? Public Health Nutrition, 9(5), 644-650. https://doi.org/10.1079/PHN2005912.

Tambe, S., Bhutia, N. T., \& Arrawatia, M. L. (2005). People's opinion on the Impacts of "Ban on Grazing” in Barsey Rhododendron Sanctuary, Sikkim, India. The Mountain Institute. Gangtok, Sikkim. Available online at: http://www.indiaenvironmentportal.org.in/files/file/barsey-sikkim.pdf.

Tambe, S., \& Rawat, G. (2009). Ecology, economics, and equity of the pastoral systems in the Khangchendzonga National Park, Sikkim Himalaya, India. AMBIO: A Journal of the Human Environment, 38(2), 95-100.

United Nations General Assembly. (2015). Transforming our world: The 2030 agenda for sustainable development. New York.

Walker, B. H., \& Salt, D. (2006). Resilience thinking: Sustaining ecosystems and people in a changing world. Washington, DC: Island Press.

Young, O. (2002). Institutional interplay: The environmental consequence of cross-scale interactions. In P. Stern, E. Ostrom, T. Dietz, \& N. Dolsak (Eds.), The drama of the commons (pp. 327-360). Washington, D.C.: National Research Council, Committee on Human Dimensions of Global Climate Change, National Academies Press. 
Young, O. R., Berkhout, F., Gallopin, G. C., Janssen, M. A., Ostrom, E., \& van der Leeuw, S. (2006). The globalization of socio-ecological systems: An agenda for scientific research. Global Environmental Change, 16(3), 304-316.

Publisher's Note Springer Nature remains neutral with regard to jurisdictional claims in published maps and institutional affiliations. 